diagnosis, frequency of follow-ups and therapy of SSc in different age groups.

Disclosure of Interests: Pia Moinzadeh Speakers bureau: Actelion, Kathrin Kuhr: None declared, Ulf Müller-Ladner Grant/research support from: Projekt supported by an unrestricted educational grant from Celgene $\mathrm{GmbH}$., Elise Siegert Shareholder of: Astra Zeneca, Grant/research support from: Actelion, Consultant for: AEC Partners, Speakers bureau: Actelion, Norsk, Jörg Henes: None declared, Gabriela Riemekasten Consultant for: Chugai, F. Hoffmann-La Roche, Speakers bureau: Chugai, F. Hoffmann-La Roche, Norbert Blank Grant/research support from: SOBI and Novartis, Speakers bureau: Novartis and SOBI, Marc Schmalzing Grant/ research support from: Pfizer, Chugai, MSD, Janssen-Cilag, BMS, Celgene, UCB, Consultant for: Abbvie, Chugai, Genzyme, Hexal/Sandoz, MSD, Novartis, Roche, Sanofi Pasteur, Speakers bureau: Actelion, Baxalta/Shire, BMS, Celgene, Chugai, Janssen-Cilag, MSD, Novartis, Pfizer, Roche, UCB, Ina Koetter: None declared, Claudia Guenther Grant/ research support from: Pfizer, Novartis, Employee of: 20 years ago, Novartis, Speakers bureau: Celtis, Tim Schmeiser Speakers bureau: Actelion, UCB, Pfizer, Gabriele Zeidler Grant/research support from:

- MSD Sharp \& Dohme GmbH

- Actelion Pharmaceuticals Deutschland GmbH

- Roche Pharma AG

- AbbVie Deutschland GmbH Co. KG

- Pfizer Pharma GmbH

- Lilly Deutschland GmbH

- Celgene $\mathrm{GmbH}$

- Bristol-Myers Squibb

UCB Pharma GmbH/UCB GmbH

- Speakers bureau:

- MSD Sharp \& Dohme GmbH

- Actelion Pharmaceuticals Deutschland GmbH

- Roche Pharma AG

- AbbVie Deutschland GmbH Co. KG

- Pfizer Pharma GmbH

- Lilly Deutschland GmbH

- Celgene GmbH

- Bristol-Myers Squibb

- UCB Pharma GmbH/UCB GmbH

Disclosure of Interests: Alexander Kreuter Speakers bureau: Actelion Pharma, MSD, AbbVie, InfektioPharm, Margitta Worm: None declared, Laura Susok: None declared, Aaron Juche: None declared, Christiane Pfeiffer: None declared, Cord Sunderkoetter: None declared, Donja Homayoon: None declared, Nicolas Hunzelmann Speakers bureau: Boehringer Ingelheim, Actelion, Pfizer, Roche

DOI: 10.1136/annrheumdis-2019-eular.1788

\section{AB0216 THE IMBALANCE OF ACTIVITIES OF PURINE AND PYRIMIDINE METABOLISM ENZYMES IN RED BLOOD CELLS OF SYSTEMIC SCLERODERMA PATIENTS}

Elena Mozgovaya, Svetlana Bedina, Andrew Trofimenko, Irina Zborovskaya, Maria Mamus, Ekaterina Tikhomirova. Federal State Budgetary Institution "Research Institute of Clinical and Experimental Rheumatology named after A.B. Zborovsky", Volgograd, Russian Federation

Background: The systemic scleroderma (SSc) is connective tissue disease of unknown cause. The key points in development of SSc are the increased number of high collagen-producing fibroblasts in the skin, endothelial dysfunction and immune activation. Recent studies report various metabolic disturbances in SSc patients. Purine and pyrimidine metabolic pathways are underlies the central processes of cellular life. The changes in activity of purine and pyrimidine metabolism enzymes in blood plasma and lysed lymphocytes depending on the SSc activity were described by us earlier [1]. At the same time, there are publications that confirm the relationship between changes in ADA activity in red blood cells and pronounced immune disorders [2].

Objectives: to characterize enzymatic patterns of the major purine and pyrimidine metabolic pathways enzymes in lysed red blood cells depending on the SSc activity.

Methods: 51 SSc patients and 30 healthy controls were enrolled in the study. The diagnosis was verified in accordance with the international standards (ACR/EULAR 2013). Disease activity was assessed in accordance with the national classification [3]. Adenosine deaminase (ADA; EC 3.5.4.4); adenosine kinase (AK; EC 2.7.1.20); guanylate kinase (GK; EC 2.7.4.8), dihydroorotate dehydrogenase (DODH; $\quad$ DC 1.3.1.14); IMP dehydrogenase (IMPDH; EC 1.1.1.205); purine nucleoside phosphorylase (PNP; EC 2.4.2.1); thymidine kinase (TK; EC 2.7.1.21); thymidine phosphorylase (TP; EC 2.4.2.4); uracil/thymidine dehydrogenase (UDH; EC 1.17.99.4); cytidine deaminase (CDA; EC 3.5.4.5) activities were measured in lysed red blood cells.

Results: Mean age of patients (Mean \pm SD) was $42.8 \pm 1$.3years, mean SSc duration was $7.9 \pm 0.7$ years. We revealed substantial changes in enzymatic activities related to both purine and pyrimidine metabolism in lysed red blood cells of SSc patients. The increased ADA $(p<0,001)$, AK $(p<0,001)$, IMPDH $(p<0,001)$, TK $(p<0,001)$, UDH $(p<0,001)$ activities and the decreased DODH $(p<0,001)$, PNP $(p<0,001)$ activities in lysed red blood cells were observed of SSc patients in comparison with healthy controls. AK, IMPDH, TK, UDH activities positively correlated with SSc activity. Negative correlations with $S S c$ activity were revealed for ADA CDA, DODG, GK, PNP, TP activities.

Conclusion: The progression of SSc goes with the imbalance of the purine and pyrimidine enzymes in a regular manner. Activity of the autoimmune inflammation is the factor that underlies the enzymatic pattern of purine and pyrimidine metabolism.

\section{REFERENCES}

[1] Mozgovaya E., Bedina S., Trofimenko A., Zborovskaya I. The association between activity of purine and pyrimidine metabolism enzymes and disease activity in systemic scleroderma patients. Annals of the Rheumatic Diseases 2018;77(2):1280.

[2] Cowan M.J., Brady R.O., Widder K.J. Elevated erythrocyte adenosine deaminase activity in patients with acquired immunodeficiency syndrome. Proc Natl Acad Sci U S A. 1986 Feb;83(4):108

[3] Guseva N.G. Systemic scleroderma. M.: Medicine,1993.268 p.

Disclosure of Interests: None declared

DOI: 10.1136/annrheumdis-2019-eular.2125

\section{AB0217 ASSOCIATION OF EUROPEAN SCLERODERMA STUDY GROUP ACTIVITY INDEX (ESCSG-AI) WITH PROGRESSION PULMONARY ALTERATIONS BY HRCT IN PATIENTSWITH SYSTEMIC SCLEROSIS OVER A FIVE YEAR PERIOD}

Olga Ovsyannikova, Lidia P. Ananyeva, Olga Koneva, Liudmila Garzanova, Oxana Desinova, Mayya Starovoytova. V.A. Nasonova Research Institute of Rheumatology, laborantory of microcirulation and inflamation, Moscow, Russian Federation

Background: Systemic sclerosis (SSc) is a rare connective tissue disease with a heterogeneous clinical course. Interstitial lung disease (ILD) is a common manifestation of SSc and a leading cause of death. Patients with early active SSc are at great risk for progressive ILD.

Objectives: To assess the EScSG-Al in patients with systemic sclerosis (SSc) and interstitial lung disease over a five year period.

Methods: It was a longitudinal study involving 77 pts with SSc-ILD (mean age was $46,2 \pm 13,4 ; 69 \%$ have limited subset of the disease; $93 \%$ were female). The mean duration of follow up was $58,9 \pm 11,4$ months. Pts were investigated with HRCT twice (at first visit and at the end of the study) and according the CT-changes were divided into 3 groups: the 1st group (16 pts) with improvement; 2nd group (39 pts) without any changes and 3rd group (22 pts) with worsening of fibrosis. Disease activity was assessed by the 2001 European Scleroderma Study Group Activity Index (EScSG- Al).

Results: There were no significant differences between groups related to sex, frequency of diffuse form and duration disease. Mean dates of EScSG-Al score of all pts and in the each groups in first visit and the end of follow up are present in table 1.

Table 1

\begin{tabular}{lccc}
\hline Groups & First visit & At the end of the study & $\mathrm{p}$ \\
\hline Group 1 $(\mathrm{n}=16)$ & $1.9 \pm 1.8$ & $1.7 \pm 0.9$ & $\mathrm{P}>0.05$ \\
Group 2 $(\mathrm{n}=39)$ & $2.0 \pm 1.5$ & $2.1 \pm 1.3$ & $\mathrm{P}>0.05$ \\
Group 3 $(\mathrm{n}=22)$ & $2.4 \pm 1.5$ & $3.25 \pm 2.0$ & $\mathrm{P}<0.05$ \\
All pts $(\mathrm{n}=77)$ & $2.2 \pm 1.6$ & $1.9 \pm 1.8$ & $\mathrm{P}>0.05$ \\
\hline
\end{tabular}

After 5 years of follow up mean values of EScSG-Al score increased significantly in group 3 and was more than 3 , this actually means the activity of the disease. The mean values of EScSG-Al score in group 3 